\title{
Is Marketing Board a Barrier or a Stimulant of Agricultural Production in West Africa? A Comparative Study of Ghana and Nigeria Cocoa Pricing Eras
}

\author{
Opeyemi Ayinde \\ Department of Agricultural Economics and Farm Management. University of Ilorin, Nigeria. \\ opeyemi@unilorin.edu.ng; opeayinde@gmail.com \\ DOI: http://dx.doi.org/10.4314/gjds.v11i2.4
}

\begin{abstract}
This study focuses on examining the marketing policies of cocoa in West Africa with specific interest in comparing the prices of cocoa during marketing board eras of Nigeria and Ghana. The objectives of this study include examining the prevailing economic situations; comparing producer prices during the different pricing eras; and evaluating the effect of the marketing board eras on cocoa production in Ghana and Nigeria. Time series data for the period 1966 to 2009, were sourced from Cocoa Research Institute, Ibadan; Cocobod Annual Report, Accra; Food and Agriculture Organization of United Nation Statistics Division (FAOSTAT) and Annual Bulletin of Statistics of the National Bureau of Statistics of Nigeria. Descriptive statistics, trend analysis and Co-Integration Analysis were used to analyse the data. Results from this study revealed that there is linear trend in the cocoa production during the marketing board era as compared to the post-marketing board era in the two countries. This is attributed to the increase in the prices experienced in post marketing board era. The study established that the marketing board era and prices affected the production of cocoa. The marketing board era had positive impact on the cocoa production although the trend analysis revealed the post marketing era has higher production. However, in Ghana the marketing board era was not significant while cocoa price was significant in explaining the variation in Ghana's cocoa production. The study recommends that Government of West Africa counties especially Nigeria and cocoa farmers should learn from the price stabilization mechanism of marketing board era especially from the Ghana reformation in order to have a sustainable economic development and policy that stimulates production.
\end{abstract}

Keywords: Cocoa, Ghana, Market Board, Nigeria, Co - integration and Price 


\section{Introduction}

High and sustained rates of agricultural growth, largely driven by productivity growth, will be necessary if African countries are to accelerate poverty reduction, reduce food insecurity, favour rural development, increase export earnings, which would have a positive spillover effect on the economic development (Ayinde, Muchie \& Babalola, 2014). Agricultural sector is faced with the challenge of declined productivity coupled with global change in climate, environment, technology, politics, economies and increasingly greater inter - dependency of nation states. Gains in overall agricultural production can therefore come from changes in the physical production level through change in technology employed in the production process, which results in more output per unit of input such as land (yields) or labour, or from changes in production and market costs and hence the increased profitability of farmers. Market cost can only be transferred to agricultural price incentives if not distorted. Distortion of agricultural price incentives is considered as one of the keys to Africa's failure (Anderson, 2009; Anderson \& Masters, 2009 and Anderson \& Bruckner, 2011). Different policies and programmes have been put in place to solve the market failure and build a constituency for reform. The absence of a stable, efficient and predictable policy environment can hinder the growth of agricultural production especially in cash crop production like cocobod production.

Teal (2013) considered the history of cocoa production in the period after the Second World War as one characterized by heavy taxation. This pattern of taxing agricultural output to implicitly subsidize an urban growth of manufacturing was general across subSaharan Africa in the period following independence and its failure to provide a basis for sustained growth was background to policies which proved so contentious (Teal, 2013). The British set up crop marketing in West Africa during the second world war, motivated by commodity price and access concerns (Bauer \& Yamey, 1968; Williams, 1953). After the world war, the preservation of marketing boards was justified primarily on the ground of price stabilisation for chronically volatile world prices (Cullinan, 1999; Hubbard \& Smith, 1994). The impact of the marketing boards on these burgeoning countries was substantial and they sometimes came to be wealthiest and economically most significant single unit in their respective economies (Bates, 2005).

While their actions were justified in terms of price stabilization, the marketing board generally used their powers simply to siphon resources away from the agricultural sector (Williams, 2009). By setting farmer payment substantially below world prices, the marketing board effectively levied a tax on farmers (Bates, 2005; Killick, 1990), which discouraged farm production and dampened farmers' income. Meanwhile, the surpluses the government accrued were rarely used to stabilize prices; instead, the generally funded industrialization and development project, primarily for urban populations were provided patronage resources for those in power (Bates, 2005; Bauer \& Yamey, 1968; Hubbard \& Smith, 1994; ul Haque, 2004; Tollens \& Gilbet, 2003). 
The marketing boards became not only the means for collecting patronage resources but also the vehicle for distributing them (Williams, 2009). Jobs within the agricultural marketing systems became rewards for party loyalties and the marketing boards soon became bloated, costly and under qualified as a result. With time, the marketing boards developed reputations for being institutions of egregious inefficiency that exploited farmers and discouraged agricultural production (Bates, 2005; Hubbard \& Smith, 1994; Shepherd \& Farolfi, 1999).

Though the World Bank and International Monetary Fund (IMF) initially supported the state-run marketing boards, their support waned with the strengthening of free market, "neo-liberal" tendencies in the international arena and the growing evidence of marketing boards' inefficiency (Hubbard \& Smith, 1996; Varangis et al., 2002; Lele \& Christiansen, 1989; Farazmad, 2002). As part of structural adjustment programmes, the World Bank and IMF sought to abolish the marketing boards and build, and declared that a 'vibrant competitive private agricultural marketing sector with direct state intervention is needed only in cases of clear market failure (Hubbard \& Smith,1996; World Bank 1994; KonaduAgyemang, 2001). International pressure instigated a wave of privatisation, and by the end of the 1990s, virtually all marketing boards in Africa had been either fully or partially privatised (Williams, 2009).

Yet, the result of these reforms could hardly be deemed a resounding success. While liberalisation produced some positive outcomes, such as initial increases in producer prices and improved promptness of payment (Shepherd \& Farolfi, 1999), even the World Bank assessments found the results of reform to be, at best mixed (Akiyama, Baffes, Larson \& Varangis, 2003; Tiffen MacDonald, Maamah \& Osei-Opare. 2004; ul Haque 2004). The vibrant and competitive private sector envisioned rarely emerged and, more crucially, the privatisation process neglected the transfer of important and positive roles being fulfilled by the state- such as quality control, input provision, extension, credit, and research and development - to private actors (Daviron \& Gibbon, 2002; Cullinan, 1999; Hubbard \& and Smith, 1996, Shepherd \& Farolfi, 1999; Poulton et al., 2005; ul Haque, 2004). Quality concerns became especially pressing after liberalisation (LMC, 1996; Shepherd \& Farolfi, 1999; AIDE, 1995). Without universal quality controls, private actors can exploit an origins reputation by marketing sub-par product for the premium quality price. This creates a vicious downward circle in product quality as the entry of subpar product into the market erodes the origin's quality reputation and reduces the price premium for a produce. In turn, this diminishes the incentives for all parties to protect the quality of their product. The result can be quality collapse, which was the outcome after cocoa market liberalisation in Cameroon, Nigeria and Cote d'ivoire (de Jong \& HartsBroekhuis, 1999; Varangis, Thigpen \& Akiyama, 1990; Fold, 2002).

The widely acknowledged policy implication of this history was that simply removing the state from marketing the system was not the solution contrary to prior neo-liberal assumptions as seen in Ghana (Cullinan, 1999; Akiyama et al. 2003). Hence this study 
answers the question of whether marketing board is a barrier or stimulant to agricultural production by considering two countries - Ghana and Nigeria as case study

\section{The History of Nigeria's Cocoa Marketing Board}

Cocoa exports have been a significant contributor to economic growth of Nigeria and as at 1993, Nigeria was the fourth largest producer of Cocoa in the world, ranking after Ivory Coast, Brazil and Ghana (Titilola, 1997). Cocoa accounted for over $90 \%$ of non-oil exports in 1985. Producers' price tripled between the 1985 and 1986 harvest and the 1986 main harvest after the Cocoa Board had previously set prices close to world prices at the official exchange rate. The re-organization of the marketing boards in 1976 gave rise to the creation of seven different commodity boards. They are cotton, grain, palm produce, groundnut, rubber, root and tuber crops boards (Idachaba \& Ayoola, 1992). Until June 1986, when the commodity boards were scrapped, the marketing and exporting of agricultural produce in Nigeria was mainly monopolized by the commodity boards. One of these boards is the Nigeria cocoa board for the cocoa produce in Nigeria. Prior to the introduction of the Structural Adjustment Programme (SAP) in 1986, Joshua (2001) specified that Nigerian cocoa beans were exported exclusively by Nigerian Cocoa Board (NCB). In terms of mode of operation, the Board had the statutory responsibility to procure cocoa beans locally and export. In doing so, it created and maintained a structure of Local Buying Agents (LBA) for the sole aim of aggregating cocoa beans from farmers in the producing areas. The boards appointed LBA who could either be companies, individuals or cooperative societies to purchase, bag, store, grade and transport to the boards' port stores.

According to Kolawole (1971), the operations of the marketing board era were criticized on the grounds that the system had failed to provide incentives to farmers to increase production. The first progress report on the current 1970/1974 development plan indicates that the system (marketing board era) as presently operated discouraged increase efforts and production by the farmers. The stagnation in the output and export of some cash crops is attributed to the marketing board system. As a result of the inefficiencies in the commodity boards system and following structural changes in the Nigerian economy in the mid-eighties, the marketing board structure was abolished by the Federal Government of Nigeria in 1986 and this gave rise to free market operations. Under the new marketing system, farmers sold to private entrepreneurs who performed various marketing functions in the Nigeria cocoa economy. Consequently, the prices at which cocoa and other cash crops farmers in Nigeria were able to sell their produce to a large extent now depended on how they responded to both local and global demand in the cocoa industry (Olubanjo Akinleye \& Ayanda, 2009). The principal objective of the new policy (post marketing board era) which started form 1988 was to increase the production of agricultural exports (Ayinde, Adewumi, Nmadi, Olatunji \& Egbugo, 2014). The purpose instrument for achieving this objective was an increase in the proportion of world price paid to producers. According to the federal government, the reasons for 
these changes was primarily to offer relatively high producer prices to our farmers and encourage them to increase their production of cocoa (Kolawole, 1971). Yet the production and export of cocoa is still stagnant and producer income is still relatively low affecting the sustainability of the country economic development, hence there is a need for the assessment of cocoa marketing in Nigeria.

\section{The History of Ghana's Cocoa Marketing System}

Cocoa is critically important to the Ghanaian people. There were around four million cocoa growers in Ghana out of a total population of about 20 million by year 2005 (EGEVAL, 2005). The history of Ghana's cocoa marketing board was part of the initial British marketing boards and became an independent unit, called the Cocoa Marketing Board (CMB) in 1947. At Ghana's independence in 1957, the country was the world's largest cocoa producer. It was also a relatively prosperous nation compared with the rest of Africa, largely because of its strong cocoa production and the relatively high world price of cocoa (Wood, 2004; Frimpong-Ansah, 1991).

However, promising beginning so soon gave way to disappointment. As was the case with many marketing boards, Ghana's political elites chronically exploited the cocoa industry and its revenues from independence until the 1980 s to pursue industrialisation, redistribute resources and bolster patronage network, with price stabilisation so far down the list of priorities as to be inconsequential (Herbst, 1993; Frimpong-Ansah, 1991; Wood, 2004; Bates, 2005; Dzorgbo, 2001; William, 2009).

By the early 1980s, there existed over-taxation and politicisation of the cocoa sector through the marketing boards. A central manifestation of politicisation in the cocoa sector was over-employment, as cocoa marketing. Jobs became a reward for political loyalties. In 1985, well over 100,ooo government employees worked in the cocoa sector. These numbers were inflated further by the existence of nearly 25000 ghost worker on the cocoa wage roll (Commander et al. 1989; William 2009).

Largely, due to Ghana's cocoa marketing board depleting the country's economic lifeblood to support patronage networks for political elites (William, 2009), in the 1983/84 season, the farmers share reached a low of 29 per cent of the FOB price (Tiffen et al. 2004; LMC 1996) coinciding with a record of low production of $168000 \mathrm{MT}$ (FAOSTAT, 2013). By the early 1980 , the cocoa industry was on the brink of collapse, along with the Ghanaian economy as a whole (Williams, 2009).

By mid 1980s cocoa rehabilitation efforts were to increase producer prices by freeing up resources from the inflated cocoa public sector (Commander et al., 1989). To this end the staff and costs of the CMB, renamed Cocoa Board (Cocobod for short) in 1984, were drastically reduced. By 1986 the reform began fully and past internal marketing systems were uniformly tarnished by rent-seeking and politicisation and this led to constant increase in cocoa production in Ghana till now unlike in Nigeria. How did Ghana's cocoa 
marketing system become a stimulant of agricultural production? Was actually the marketing board eras having linkage with the agricultural production? What is the effect of producer price on agricultural production? Do the farmers get increase in income or that it is been exploited away by the cocoa marketing board?

\section{Methodology}

This study area was West Africa. The Federal Republic of Nigeria and the Republic of Ghana were purposively chosen because of their similarity in that the two countries were the most important British colonies in West Africa. The set of data for this study was time series data from secondary sources. Nigeria has two marketing board eras - (1960 to 1985 ) and post marketing era (1986 to date). Ghana too has two marketing Board eras - (1957 to 1985) and Reformed Marketing board era called Cocobod (1986-till date). The data collected were for the period of 1966 to 2009. These data were obtained from Cocoa Research Institute; Ibadan; Cocobod Annual Reports, Accra; World Bank; FAOSTAT; annual bulletin of statistics on cocoa and relevant published materials such as journals and books.

Three major tools of analysis were employed in this study. They are descriptive statistics, trend analysis and co-integration analysis. Trend analysis was used to compare the producer price and agricultural output of cocoa of the two marketing boards eras in the two countries. Estimation of the trend line used in this study involves the use of least square method used to decide whether there is a statistically significant trend in price over time in the two eras. The Ordinary Least Square (OLS) equation is;

$Y t=a+\beta t+e t, t=1,2, \ldots, 44$

Where: $\mathrm{t}=$ time, Yt $=$ trend values with respect to time $(\mathrm{t})$, Et $=$ error term, which is assumed to be identically and independently distributed with mean zero and constant variance, that is et $\sim$ NIID $\left(o . a^{2}\right)$. The test statistic is used as a measure of significance of trend. In fact, this test statistic is used to test the null hypothesis: There is no monotonic trend. P-value is the probability which determines the appropriateness of rejecting the null hypothesis in a hypothesis test. P-values range from o to 1 . The commonly used significance level is $\mathbf{Q}=0.05$. If the $\mathrm{P}$-value is less than the $\mathbf{a}$, the null hypothesis is rejected. In this case, the null hypothesis is that there is no trend in the data. Hence, if a P-value less than 0.05 then the trend are significant. So the smaller the P-value, the more significant the trend.

Co-integration process evaluates the effect of marketing board eras on cocoa production. This process integrates short-run dynamics with long run equilibriums (Maddala, 2001). Co-integration analysis as it was developed by Granger (1981), elaborated in Engle and Granger (1987), adapted and used by Obasi (2007) and Olubusoye and Oyeromade (2008) firstly involve the test for unit root or stationary test. The augmented Dickey-fuller (ADF) test was used for the test. The ADF F-ratio critical value was used to make decision on the 
stationary of the variables. The Johansen technique was used to test for co-integration in the model. Johansen technique was used not only because it is vector auto -regressive based but because it performs better in multivariate model. The model is shown as follows:

$$
L Y_{t}=\beta_{o}+\beta_{1} L X_{1 t}+\beta_{2} L X_{2 t}+e_{t}
$$

Where;

$\mathrm{Y}_{1}=$ output (cocoa production), $\mathrm{X}_{1}=$ Era $\mathrm{X}_{2}=$ Producer price, $\mathrm{t}=$ Time

$e_{t}=$ error term .The error term was tested for unit root for reconfirmation of cointegration.

\section{Results and Discussions}

\section{Trend Analysis}

Figure (1) shows Cocoa Output is relatively stable in Nigeria than in Ghana. However, there was a constant increment in cocoa output from 1992.

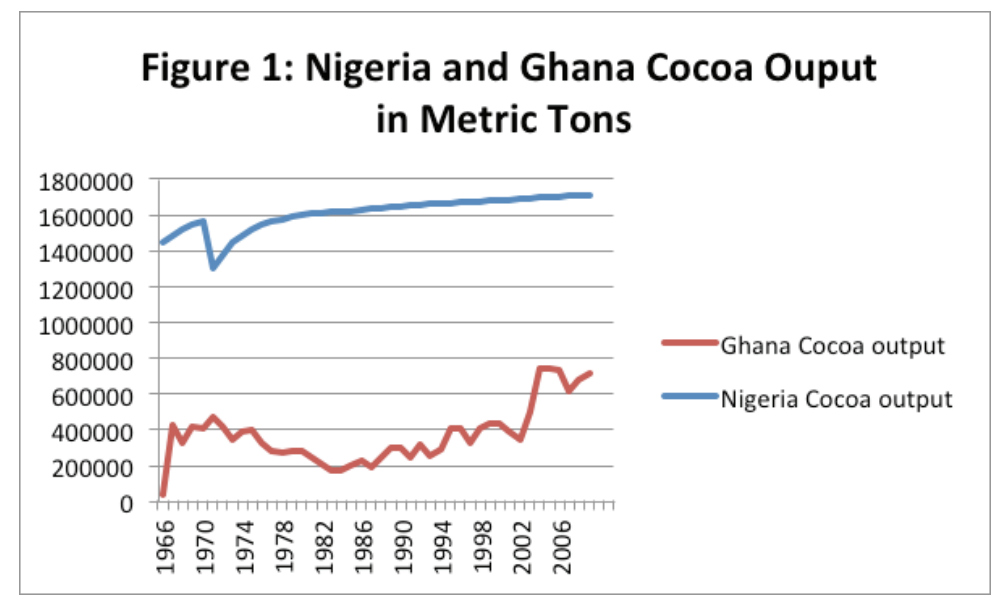

Figure shows that Nigerian prices of cocoa stabilized for the years 1971, 1972 and 1973 at 297. It also stabilized for the years 1977, 1978, 1980, 1981and 1982 at 1300 . However, Ghanaian prices of Cocoa were not stable as they recorded increases and 1985 the increase was as high as 52160 cedis. In the case of Nigeria, during post marketing board era, prices were not stable in between years but the price reached the peak in 2006 at the rate of N2, 431,785. This may be due to political changes because the government as at that time introduced SAP (Structural Adjustment Programme) and the exchange rate changed which led to the high value of dollar and thus has a nominal high increase in the price of cocoa. 
Figure 2: Price of cocoa during the marketing board era in Nigeria and Ghana

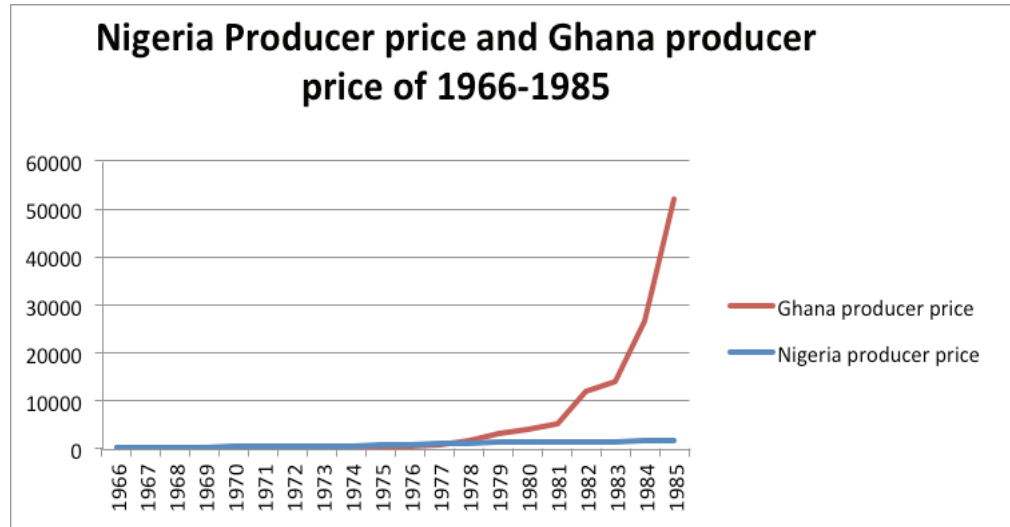

In the case of Ghana in the second era, cocoa price was continuously rising until 2008 when it fell to 1200 cedis as shown in Figure (3).

Figure 3: Price of cocoa during Nigeria post-marketing board era and Ghana Cocobod era

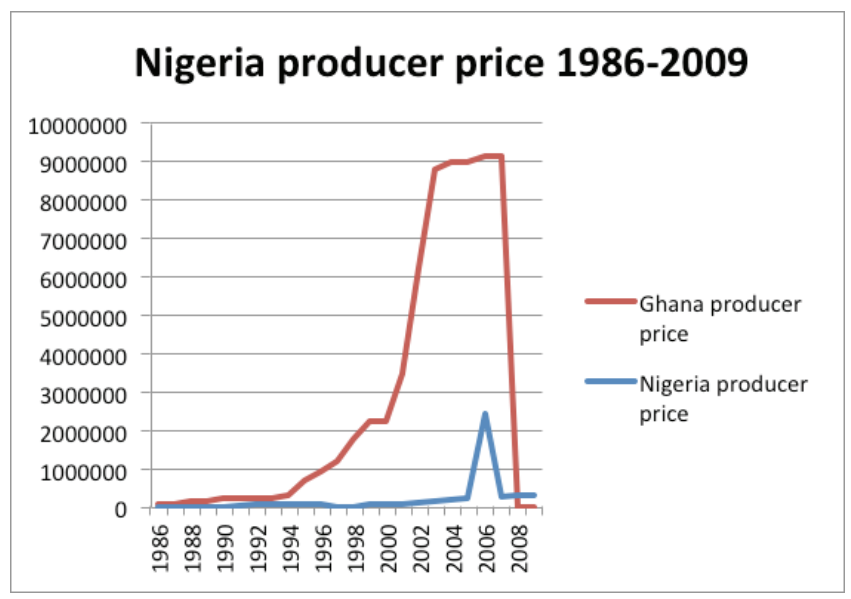

Tables (1) shows the Ghana producer price trend and Nigeria Producer price trend respectively. It was therefore concluded that there was linear relationship between the producer price and the period of occurrence in both countries. This means there is a trend relationship in the data of both countries. 
Table 1 Ghana producer price trend analysis

\begin{tabular}{|c|c|c|c|c|}
\hline & \multicolumn{2}{|c|}{ Unstandardized Coefficients } & $\begin{array}{l}\text { Standardized } \\
\text { Coefficients }\end{array}$ & Sig. \\
\hline Ghana & B & Std. Error & B & \\
\hline $\begin{array}{l}\text { yearooo5 } \\
\text { iaoard Era } \\
\text { countries. }\end{array}$ & 147367.74 & 28635.26 & .622 & .000 \\
\hline (Constant) & -291498242.19 & 56933203.22 & & .000 \\
\hline Nigeria & & & & \\
\hline Year & 11529.54 & $4199 \cdot 39$ & .390 & .009 \\
\hline (Constant) & -22814997.78 & 8349305.11 & & .009 \\
\hline
\end{tabular}

Dependent Variable: Producer price

$Y_{t}=\alpha+\beta t+e_{t}$

$Y_{t}=147367.74+291498242.19 t$ (Ghana trend line)

$Y_{t}=-22814997.78+11529 \cdot 54 t$ (Nigeria trend line)

\section{Hypotheses}

$\mathrm{H}_{\mathrm{o}}$ : No trend in the data versus $\mathrm{H}_{1}:$ Not $\mathrm{H}_{\mathrm{o}}$ (there is trend in the data)

Decision rule: reject $\mathrm{H}_{\mathrm{o}}$ if $\mathrm{p}$-value is less than 0.05 , otherwise do not reject.

Decision: since the $\mathrm{p}$-value is less than 0.05 we reject $\mathrm{H}_{\mathrm{o}}$

The result of the Granger Analysis for Ghana shows there is unidirectional linkage between the Ghana cocoa output and producer prices and producer price is significantly granger cause Cocoa Output (Table 2).

Table 2: Result of Granger Analysis for Ghana

\begin{tabular}{|l|l|l|}
\hline Pairwise Granger Causality Tests & & \\
\hline Sample: 1966 2009 Lags:2 & & \\
\hline Null Hypothesis: & F-Statistic & Prob. \\
\hline PRODUCER_PRICE does not Granger Cause COCOA_OUTPUT & 5.47383 & 0.0083 \\
\hline COCOA_OUTPUT does not Granger Cause PRODUCER_PRICE & 0.86235 & 0.4305 \\
\hline
\end{tabular}


In Nigeria, however, table 3 shows that there is no causality relationship in the Nigeria Cocoa output and producer price. The price of cocoa does not transform to production. This may be due to the exploitative nature of marketing board (era) and the post market board era did not perform better as the gains in production was likely gotten by middlemen or merchants and not the producers of cocoa production.

Table 3: Result of Granger Analysis for Nigeria

\begin{tabular}{|l|l|l|}
\hline Pairwise Granger Causality Tests & & \\
\hline Sample: 1966 2009 Lags:2 & & \\
\hline Null Hypothesis: & F-Statistic & Prob. \\
\hline PRODUCER_PRICE does not Granger Cause COCOA_OUTPUT & 0.10741 & 0.8984 \\
\hline COCOA_OUTPUT does not Granger Cause PRODUCER_PRICE & 1.04530 & 0.3617 \\
\hline
\end{tabular}

\section{Co-integration test}

In table (4), The Augmented Dickey Fuller stationary test shows Nigeria's cocoa output variables exhibit unit root at the level that they are non-stationary. But at first differencing, Ghana's output and price became stationary except Nigeria's producer that became stationary at second differencing. The differencing is needed in order to avoid having a spurious regression. Since the differenced variables are stationary, there is co-integration between the variables; this means that there is a long run relationship between the output, era and producer price.

Table 4: Result of stationary test from augmented Dickey-Fuller Test

\begin{tabular}{|l|l|l|l|l|l|l|}
\hline Country & Variables & Level & $1^{\text {st }}$ difference & $\begin{array}{l}2^{\text {nd }} \\
\text { difference }\end{array}$ & $\begin{array}{l}\text { Order of } \\
\text { integration }\end{array}$ & Decision \\
\hline \multirow{3}{*}{ Ghana } & $\begin{array}{l}\text { Cocoa } \\
\text { Output }\end{array}$ & -1.85788 & $-9.079165^{* * *}$ & $-5.175345^{* * *}$ & $\begin{array}{l}\text { I (1) Stationary } \\
\text { at first } \\
\text { difference }\end{array}$ & $\begin{array}{l}\text { Non- } \\
\text { stationary }\end{array}$ \\
\cline { 2 - 7 } & $\begin{array}{l}\text { Producer } \\
\text { Price }\end{array}$ & -2.316704 & $-4.675183^{* * *}$ & -2.013954 & $\begin{array}{l}\text { I (1) Stationary } \\
\text { at first } \\
\text { difference }\end{array}$ & $\begin{array}{l}\text { Non- } \\
\text { Stationary }\end{array}$ \\
\hline \multirow{3}{*}{ Nigeria } & $\begin{array}{l}\text { Cocoa } \\
\text { Output }\end{array}$ & $-3.852287^{*}$ & $-3.543279^{* *}$ & $-3.453810^{* *}$ & $\begin{array}{l}\text { I (o) Stationary } \\
\text { at level }\end{array}$ & Stationary \\
\cline { 2 - 7 } & $\begin{array}{l}\text { Producer } \\
\text { Price }\end{array}$ & 7.267932 & -0.960187 & $-6.076280^{* * *}$ & $\begin{array}{l}\text { I (1) Stationary } \\
\text { at second } \\
\text { difference }\end{array}$ & $\begin{array}{l}\text { Non- } \\
\text { Stationary }\end{array}$ \\
\hline
\end{tabular}

Note: critical value: $1 \%$ denotes by ${ }^{* * *}, 5 \%$ denotes by ${ }^{* *}$ and $10 \%$ denotes by ${ }^{*}$ 
Johansen Co-integration result is shown in Table (5). There were two co-integrating (CI) equations in the analysis for both countries. Only one of the $\mathrm{CI}$ equations was chosen. The CI equation chosen was based on the conformity of the coefficients with the economic theory and its statistical significance.

Table 5: Johansen co-integration result

\begin{tabular}{|l|l|l|l|l|l|}
\hline & $\begin{array}{l}\text { Hypothesized } \\
\text { No. of CE(s) }\end{array}$ & $\begin{array}{l}\text { Egien } \\
\text { value }\end{array}$ & $\begin{array}{l}\text { Trace } \\
\text { statistics }\end{array}$ & $\begin{array}{l}\text { o.o5 critical } \\
\text { value }\end{array}$ & Prob.* \\
\hline Ghana & None & 0.277919 & 23.01090 & 29.79707 & 0.2455 \\
\hline & At most 1 & 0.127919 & 9.334921 & 15.49471 & 0.3353 \\
\hline & At most 2* & 0.081843 & 3.586249 & 3.841466 & 0.0583 \\
\hline Nigeria & None & 0.104300 & 5.355220 & 15.49471 & 0.7700 \\
\hline & At most 1 & 0.017206 & 0.728930 & 3.841466 & 0.3932 \\
\hline & At most 2 & & & & \\
\hline
\end{tabular}

Trace test indicates 1 co-integration equation(s) at the 0.05 level. *denotes rejection of the hypothesis at the $10 \%$

From the equation in table 6, cocoa price is significant in determining output (cocoa production) in Ghana during the period studied. $\mathrm{X}_{1}$ is significant at 1\% (table 6). Therefore, the variables are positively co-integrated because the independent variables determined the output of cocoa production. The marketing board eras are not significant in determining cocoa production. This implies that the marketing board era had no effect on cocoa production as it was the political and exploitative factor that was removed in the first era. And this reformation transformed into better price for the cocoa producer which in turn affected the cocoa production positively. These empirical findings are in conformity with the qualitative explanation in William's (2009) study.

Table 6: Co-integration Regression Result for Ghana

Dependent Variable: COCOA_OUTPUT

Method: Fully Modified Least Squares (FMOLS)

Sample (adjusted): 244

Included observations: 43 after adjustments

Cointegrating equation deterministics: $C$

Regressor equations estimated using differences

Additional regressor deterministics: @TREND@TREND^2 
Long-run covariance estimate (Bartlett kernel, Newey-West fixed bandwidth $=4.0000$

\begin{tabular}{|l|l|l|l|l|}
\hline Variable & Coefficient & Std. Error & t-Statistic & Prob. \\
\hline ERA & 18308.75 & 44303.04 & 0.413262 & 0.6816 \\
\hline PRODUCER_PRICE & 0.040402 & 0.007469 & 5.409105 & 0.0000 \\
\hline C & 286161.1 & 67460.41 & 4.241912 & 0.0001 \\
\hline R-squared & 0.347207 & Mean dependent var & 376519.6 \\
\hline Adjusted R-squared & 0. et al 314567 & S.D. dependent var & 157525.4 \\
\hline S.E. of regression & 130416.7 & \multicolumn{2}{|l|}{ Sum squared resid } & $6.80 \mathrm{E}+11$ \\
\hline Durbin-Watson stat & 0.560346 & \multicolumn{2}{|l|}{ Long-run variance } & $1.64 \mathrm{E}+10$ \\
\hline
\end{tabular}

From the equation in table 7, cocoa price was not significant in determining output (cocoa production) in Nigeria during the period studied (Table 7). The era of the marketing board was significant at 1\%. This supported the finding of Ayinde et al, 2014b. The implication of this is that the marketing board era had positive impact on the output of cocoa than the post marketing board era. Although from the descriptive statistics the maximum output of the marketing board era was lower than that of the post marketing board era, it still does not mean that post marketing board era is better than the marketing board era. The standard deviation of the marketing board era is more than that of the post marketing board era. This shows that the marketing board era determined cocoa output positively.

\section{Table 7: Co-integration regression result for Nigeria}

Dependent Variable: COCOA_OUTPUT

Method: Fully Modified Least Squares (FMOLS)

Sample (adjusted): 1967, 2009

Included observations: 43 after adjustments

Co-integrating equation deterministics: $\mathrm{C}$

Regressor equations estimated using differences

Additional regressor deterministics: @TREND

Long-run covariance estimate (Bartlett kernel, Newey-West fixed bandwidth $=4.0000$

\begin{tabular}{|l|l|l|l|l|}
\hline Variable & Coefficient & Std. Error & t-Statistic & Prob. \\
\hline ERA & 142699.1 & 30123.77 & 4.737093 & 0.0000 \\
\hline PRODUCER_PRICE & 0.032150 & 0.040636 & 0.791168 & 0.4335 \\
\hline
\end{tabular}




\begin{tabular}{|l|l|l|l|l|}
\hline C & 1391328. & 48165.39 & 28.88647 & 0.0000 \\
\hline R-squared & 0.551693 & Mean dependent var & 1617220. \\
\hline Adjusted R-squared & 0.529278 & S.D. dependent var & 91836.49 \\
\hline S.E. of regression & 63008.28 & Sum squared resid & $1.59 \mathrm{E}+11$ \\
\hline Durbin-Watson stat & 0.743832 & Long-run variance & $8.95 \mathrm{E}+09$ \\
\hline
\end{tabular}

\section{Conclusion and Recommendation}

This study has established that marketing board era and prices affected the production of cocoa production. In Nigeria, only marketing board era had positive impact on the cocoa production. Although the trend analysis revealed the post marketing era had higher production era. In Ghana, only the producer price had effect on the cocoa production. It can be concluded that marketing Board without exploitative system is not a barrier but if exists with exploitative system can make it a barrier. If it is reformed as in the case of Ghana, it can be a stimulant.

Based on the analysis of this study, there are opportunities to be developed as a nation if the cocoa farmer focuses on maintaining a relatively increasing cocoa production as cocoa is one of the non-oil export commodities in Nigeria and Ghana. Cocoa production (output) can be increased if there is stability of prices. Thus, this study recommends that Government of West African countries especially Nigeria and cocoa farmers should learn from the price stabilization mechanism of marketing board era but its exploitative factors should not be emulated to allow the farmers to experience and reap the benefits of higher output. The government should move away from direct involvement in running the economy such as the marketing of cocoa. To this end, programmes and policies that would help to increase cocoa production should be incorporated, well organized and monitored. Likewise, programmes and policies that would help to check and stabilize the price of cocoa output should be employed.

\section{References}

AIDE (1995). Memoire on the liberalisation of the cocoa sector, presented to the World Bank during the mission of the ICCO to Washington, pp. 6-8.

Akiyama, T., Baffes, J., Larson, D., and Varangis, P. (2003). Commodity market reform in Africa: Some Recent Experience, World Bank Policy Research Working Paper 2995, Washington DC: World Bank.

Anderson, K. (ed.) (2009). Distortions to agricultural incentives: A Global Perspective, 1955-2007, London: Palgrave Macmillan and Washington DC: World Bank. 
Anderson, K. and Brückner, M. (2011). Price distortions and economic growth in subSaharan Africa, CEPR Discussion Papers 8530, C.E.P.R. Discussion Papers.

Anderson, K. and Masters, W. (eds.) (2009). Distortions to agricultural incentives in Africa, Washington DC: World Bank.

Awopetu, J.A (2001). Farmers guide to cocoa and cashew production. Unilorin Press Ilorin, Kwara state, Nigeria. 9- 10. 1st Edition.

Ayinde, O.E. Muchie, M. and Babalola, F.D. (2014)a. Systems of innovation and agricultural productivity in African economies. AFRREV STECH 3(2), pp. 1-17. http:// dx.doi.org/10.4314/stech.v3i2.1.

Ayinde, O.E. Adewumi, M.O. Nmadu, J.N. Olatunji, G.B. and Egbugo, K. (2014) Review of marketing board policy: Comparative Analysis Cocoa of pricing Eras in Nigeria. Nigeria Journal of Agricultural Economics 4(1), pp. 80-92.

Baffes, J. Larson, D. and Varangis, P. (2003). Commodity market reform in Africa: Some recent experience, World Bank Policy Research Working Paper 2995, Washington DC: World Bank.

Bates, R.O. (2005). Markets and states in tropical Africa: The political basis of agricultural policies, Berkeley: University of California Press.

Bauer, P.T. and Yamey, B.S. (1968). Markets, market control, and marketing reform, Letchworth, UK: Garden City Press.

Commander, S. Howell, S. and Seini, W. (1989). Ghana: 1983-7, in Simon Commander (ed.), Structural adjustment and agriculture theory and practice in Africa and Latin America, London: ODI: pp. 107-26.

Cullinan, C. (1999). Law and markets: Improving the legal environment for agricultural marketing, FAO Agricultural Services Bulletin 139, Rome: FAO IDS WORKING PAPER pp. $318-340$.

Daviron, B. and Gibbon, P. (2002). Global commodity chains and African export agriculture', Journal of Agrarian Change 2(2), pp. 137-51.

De Jong, A. and Harts-Broekhuis, A. (1999). Cocoa production and marketing in Cameroon and Ghana: The effects of structural adjustment and liberalisation, in Laurens van der Laan, Tjalling Dijkstra and Aad van Tilburg (eds), Agricultural Marketing in Tropical Africa: Contributions from the Netherlands, Ashgate: Aldershot: pp. 87-108.

Dzorgbo, Dan-Bright (2001). Ghana in Search of Development: The Challenge of Governance, Economic Management and Institution Building, Aldershot: Ashgate. 
EGEVAL, (2005). Ghana: Country Strategy Evaluation: Volume II - Annexes, evaluation for the European Commission.

Engle R.F. and Granger, C.W.J. (1987). Co-integration and error correction: Representation, estimation and testing, Econometrica 55(22), pp. 251-276.

FAO (Food and Agriculture Organization of the United Nations). (2001). FAO Bulletin of Statistics, 2 (2), 2001. Rome, Italy.

FAOSTAT (n.d.). Cocoa Beans Production, Metric Tons, available: http://faostat.fao.org/ (accessed 10 Feburary 2013).

\section{FAOSTAT/FAO Statistics Division 2012. Accessed 6 ${ }^{\text {th }}$ April 2012.}

Farazmand, A. (2002). Administrative reform and development: An introduction, in A. Farazmand (ed.), administrative reform in developing nations, London: Praeger.

Fold, N. (2002). Lead firms and competition in bi-polar commodity Chains: Grinders and Branders in the Global Cocoa-Chocolate Industry', Journal of Agrarian Change 2.2, pp. 228-247.

Frimpong-Ansah, J. (1991). The vampire state in Africa: The political economy of decline in Ghana, London: James Currey.

Granger, C.W.J. (1981). Some properties of time series data and their use in Econometric Model Specification. Journal of Econometrics. 16(1), pp. 121-130.

Herbst, J. (1993). The politics of reform in Ghana, 1982-1991, Oxford: University of California Press.

Hill, P. (1963). Migrant Cocoa-farmers of southern Ghana, Cambridge University Press.

Hubbard, M.l and Smith, M. (1996). Agricultural marketing sector review. The Role of Government in Adjusting Economies, Paper 6, Birmingham: University of Birmingham Development Administration Group.

- (1994). Crop Purchasing. The Role of government in adjusting economies: Literature Review, Paper 1, Birmingham: University of Birmingham Development Administration Group: pp. 33-37.

Idachaba, F.S and Ayoola, G.B, (1992). "Market intervention policy in Nigeria agriculture". An export evaluation of the technical committee in prices development policy review. 9 , pp. 289-299.

Joshua, O.A (2001). Market Power in Nigerian domestic cocoa supply chains. Department of Agricultural Economics and Extension, Ladoke Akintola University of Technology. Unpublished Thesis. 
Killick, T. (1990). Markets and Governments in agricultural and industrial adjustment, ODI Working Paper 34, London: ODI.

Kolawole, M.I (1971) "The reforms of commodity marketing boards in nigeria; an analysis of new producer price policy".

Konadu-Agyemang, K. (2001). IMF and World Bank sponsored structural adjustment programs in africa: ghana's experience 1983-1999, Aldershot: Ashgate.

Lele, U. and Christiansen, R. (1989). Markets, marketing boards, and cooperatives in africa: issues in adjustment policy, MADIA Discussion Paper 11, Washington DC: World Bank.

LMC International (1996). Final Report: The external marketing of Ghana's cocoa, prepared for the ministry of finance on behalf of the government of Ghana.

Maddala G.S. (2001). Introduction to Econometrics $3^{\text {rd }}$ Edition New York: John Wiley and Sons Ltd, pp. 513-514, 543-570.

McPhee, A. (1971). The economic revolution in british West Africa, Second Edition, Frank Cass and Co. Ltd.

Obasi, O.U. (2007). "relative price variability and inflation: evidence from agricultural sector in Nigeria" AERC Research Paper 171 African Economic Research Consortium, Nairobi.

Ogunleye, K.Y and Oladeji, J.O. (2007). Choice of cocoa market channels among cocoa farmers in ila local government area of Osun state, Nigeria. Middle-East Journal of Scientific Research. 2(1), pp. 14-20.

Olatunbosun, D. and Olayide, S.O. (1972). "Trends in prospect for Nigerian commodity exports". Ibadan: Nigerian Institute of Social and Economic Research (NISER): pp. 229.

Olubanjo, 0.0., Akinleye, S.o. and Ayanda, T.T. (2009). Economic deregulation and supply response of cocoa farmers, Journal of Social Science 21(2), pp. 129-135.

Olubusoye, O.E. and Oyeromade R. (2008). Modelling the inflation process in Nigeria, AERC Research Paper. No 182. African Economic Research Consortium, Nairobi.

Poulton, C., Gibbon, P., Hanyani-Mlambo, B., Kydd, J., Wilbard M., Larsen, M., Osorio, A., Tschirley, D., and Zulu, B. (2005). Competition and coordination in liberalized African cotton market systems', in Frank Ellis and H. Freeman (eds), Rural livelihoods and poverty reduction, Routledge: pp. 166-182 Research Report, Oxford: Oxford University Press.

Shepherd, A. and Farolfi, S. (1999). Export crop liberalisation in Africa: A Review, FAO Agricultural Services Bulletin 135, Rome: Food and Agriculture Organization (FAO). 
Teal, F. (2013). Agricultural revolution in Ghana paper presented at CSAE 2013 Conference Economic Development in Africa. Held at Centre for the Study of Africa Economics, Oxford 17-19 March, 2013.

Tiffen, P. MacDonald, J. Maamah, H. and Osei-Opare, F. (2004). Tree minders to global players: Cocoa farmers in Ghana', in Merilyn Carr (ed), Chains of Fortune: Linking women producers and workers with global market, London: Commonwealth Secretariat: pp 11-44.

Titilola, S.T. (1997). “An econometric model for Nigeria's agricultural sector with emphasis on the future of cocoa in the Nigerian economy (1970-1990)".Ibadan: Nigerian Institute of Social and Economic Research (NISER): pp. 16-19.

Tollens, E. and Gilbert, c. (2003). 'Does market liberalisation jeopardise export quality? Cameroonian cocoa, 1988-2000', Journal of African Economies 12(3), pp. 303-42.

ul Haque, I. (2004). Commodities under neoliberalism: The case of cocoa, G-24 Discussion Paper Series 25, Geneva: United Nations Conference on Trade and Development (UNCTAD).

Varangis, P. Larson, D. and Anderson, J. (2002). Agricultural markets and risks: Management of the latter, not the former, World Bank Policy Research Working Paper 2793, Washington DC: World Bank.

Varangis, P. Thigpen, E. And Akiyama, T. (1990). Recent developments in marketing and pricing systems for agricultural export commodities in Sub-Saharan Africa, World Bank Policy Research Working Paper 431, Washington DC: World Bank.

Williams, T. (2009). An Africa success story: Ghana's Cocoa marketing system IDS Working Paper Series 318 Published by Institute Development of Studies UK. Available on www2.ids.ac.uk/gdr/cfs/pdfs/Wp318.pd (accessed on 5th January, 2013).

Woods, D. (2004). 'Predatory elites, rents and cocoa: A comparative analysis of Ghana and Ivory Coast', Commonwealth and Comparative Politics 42(2), pp. 224-41 IDS WORKING PAPER 31846.

World Bank (1995). Ghana: Growth, private sector, and poverty reduction, Report 14111-GH. Available from: www-wds.worldbank.org (accessed on 20 January, 2013)

- - (1994) Adjustment in Africa: Reforms, results, and the road ahead, Report 12852- Africa. Available from: www-wds.worldbank.org (Accessed 2oth January, 2013). 